\title{
A New Perspective at the Ship-Air-Sea-Interface: The Environmental Impacts of Exhaust Gas Scrubber Discharge
}

\begin{abstract}
Sonja Endres ${ }^{1,2 *}$, Frank Maes ${ }^{3}$, Frances Hopkins ${ }^{4}$, Katherine Houghton ${ }^{5}$, Eva M. Mårtensson ${ }^{6}$, Johannes Oeffner ${ }^{7}$, Birgit Quack ${ }^{8}$, Pradeep Singh ${ }^{9}$ and David Turner ${ }^{10}$
\end{abstract}

${ }^{1}$ Biological Oceanography, GEOMAR Helmholtz Centre for Ocean Research, Kiel, Germany, ${ }^{2}$ Climate Geochemistry, Max Planck Institute for Chemistry, Mainz, Germany, ${ }^{3}$ Faculty of Law and Criminology, Maritime Institute, Ghent University, Ghent, Belgium, ${ }^{4}$ Plymouth Marine Laboratory, Plymouth, United Kingdom, ${ }^{5}$ Institute for Advanced Sustainability Studies, Potsdam, Germany, ${ }^{6}$ Department of Earth Sciences, Uppsala University, Uppsala, Sweden, ${ }^{7}$ Fraunhofer Centre for Maritime Logistics and Services, Hamburg, Germany, ${ }^{8}$ Chemical Oceanography, GEOMAR Helmholtz Centre for Ocean Research, Kiel, Germany, ${ }^{9}$ Centre for Marine Environmental Sciences and Faculty of Law, University of Bremen, Bremen, Germany,

${ }^{10}$ Department of Marine Sciences, University of Gothenburg, Gothenburg, Sweden

OPEN ACCESS

Edited by:

Julian Blasco,

Consejo Superior de Investigaciones Cientificas (CSIC), Spain

Reviewed by: Juan Moreno Gutiérrez, University of Cádiz, Spain Annalaura Mancia,

University of Ferrara, Italy

${ }^{*}$ Correspondence:

Sonja Endres

sonja.endres@mpic.de

Specialty section: This article was submitted to Marine Pollution, a section of the journal Frontiers in Marine Science

Received: 08 February 2018 Accepted: 06 April 2018 Published: 24 April 2018

Citation:

Endres S, Maes F, Hopkins F, Houghton $K$, Mårtensson EM,

Oeffner J, Quack B, Singh P and Turner D (2018) A New Perspective at the Ship-Air-Sea-Interface: The Environmental Impacts of Exhaust Gas Scrubber Discharge.

Front. Mar. Sci. 5:139.

doi: 10.3389/fmars.2018.00139
Shipping emissions are likely to increase significantly in the coming decades, alongside increasing emphasis on the sustainability and environmental impacts of the maritime transport sector. Exhaust gas cleaning systems ("scrubbers"), using seawater or fresh water as cleaning media for sulfur dioxide, are progressively used by shipping companies to comply with emissions regulations. Little is known about the chemical composition of the scrubber effluent and its ecological consequences for marine life and biogeochemical processes. If scrubbers become a central tool for atmospheric pollution reduction from shipping, modeling, and experimental studies will be necessary to determine the ecological and biogeochemical effects of scrubber wash water discharge on the marine environment. Furthermore, attention must be paid to the regulation and enforcement of environmental protection standards concerning scrubber use. Close collaboration between natural scientists and social scientists is crucial for progress toward sustainable shipping and protection of the marine environment.

Keywords: scrubber, sulfur emissions, shipping, air-sea interface, surface ocean, biogeochemistry, exhaust gas cleaning system

\section{BACKGROUND: SHIP EMISSIONS AND THE AIR-SEA INTERFACE}

As international maritime transport continues to increase (Smith et al., 2015), there is growing concern about its sustainability and environmental impacts, ranging from effects on marine ecosystems to human health. Approximately $80 \%$ of the fuel used in commercial shipping in 20072011 was low-grade, high-sulfur content fuel (Smith et al., 2015), which emits significant amounts of carbon dioxide $\left(\mathrm{CO}_{2}\right)$, sulfur oxides $\left(\mathrm{SO}_{\mathrm{x}}\right)$, nitrogen oxides $\left(\mathrm{NO}_{\mathrm{x}}\right)$, aerosols [with particle matter (PM), containing organic carbon (OC), black carbon (BC), polycyclic hydrocarbons (PAHs), and heavy metals] to the atmosphere during combustion (Cooper and Gustafsson, 2004; Eyring et al., 2005). Some of these compounds have a limited residence time in the atmosphere, deposit relatively close to the source vessel and become dissolved or suspended in the surface ocean. 
In recent decades, global and regional efforts to reduce the environmental impact of ship emissions have been made. In order to reduce sulfur emissions from shipping, limits were included in international regulations adopted by the International Maritime Organization (IMO) ${ }^{1}$, such as Annex VI of the International Convention for the Prevention of Marine Pollution from Ships (MARPOL, 2017) and the European Union's Sulphur Directive (EU, 2016). International law treats the atmosphere and the ocean very differently, although they are tightly linked via chemical, physical, and biological processes. Emissions of gases and particulates to the atmosphere affect the surface ocean directly and indirectly through deposition and dissolution of gases, as well as via radiative forcing effects on the climate. Similarly, discharge of pollutants and contaminants to the ocean may reach the atmosphere by outgassing and aerosol production (Brévière and the SOLAS Scientific Steering Committee, 2016).

Several sulfur abatement techniques already exist including novel engine technologies, exhaust gas recirculation and fuel emulsifiers. Exhaust gas cleaning systems operating in open loop mode, referred to colloquially as "scrubbers," are lowcost and therefore preferred alternatives to high-cost, low-sulfur fuel. Scrubber technology primarily removes $\mathrm{SO}_{\mathrm{x}}$, from ships' exhaust, and $\mathrm{NO}_{\mathrm{x}}$ and particles to some degree, but not $\mathrm{CO}_{2}$. In open loop operation, the scrubber wash water including all contaminants, in certain cases filtered and diluted, is discharged to the surface ocean. The environmental benefits of scrubber use are questionable and their regulation is poor. Given their increasing use and the urgency of addressing pollution from maritime transport, it is crucial that natural and social scientists work together to clarify both the environmental and legal implications of scrubbers.

The International Surface Ocean - Lower Atmosphere Study (SOLAS) project is a research initiative aiming to understand the key biogeochemical-physical interactions and feedbacks between the ocean and atmosphere. In October 2016, 10 researchers from the fields of natural and social science met for a SOLASinitiated workshop to discuss the impacts of ship emissions on biogeochemical processes at the air-sea interface (Figure 1) and their socio-economic relevance. One aim of the workshop was to identify future research priorities at the ship-air-sea interface using emissions from scrubber systems as an example. The results of the workshop are summarized in this joint review.

\section{EFFECTS OF SHIP EMISSIONS ON THE ATMOSPHERE, MARINE BIOGEOCHEMISTRY AND HUMAN HEALTH}

Through fuel combustion, ship traffic significantly contributes $\mathrm{SO}_{\mathrm{x}}$ (including $\mathrm{SO}, \mathrm{SO}_{2}, \mathrm{SO}_{3}, \mathrm{~S}_{2} \mathrm{O}, \mathrm{S}_{6} \mathrm{O}_{2}, \mathrm{~S}_{2} \mathrm{O}_{2}$ ), $\mathrm{NO}_{\mathrm{x}}$ (including $\mathrm{NO}$ and $\mathrm{NO}_{2}$ ), and aerosols to the atmosphere on local and regional scales. Their wide-ranging consequences for

${ }^{1}$ IMO. Status of Treaties. Available online at: http://www.imo.org/en/About/ Conventions/StatusOfConventions/Documents/Status\%20of\%20Treaties.pdf the atmosphere, the marine environment, and human health (Corbett et al., 2007) are summarized in this section.

\section{Sulfur}

The trace gas sulfur dioxide $\left(\mathrm{SO}_{2}\right)$ is produced naturally via the atmospheric oxidation of the biogenic marine trace gas dimethyl sulfide (DMS), as well as being emitted during volcanic eruptions (Liss et al., 1997). The oxidation of $\mathrm{SO}_{2}$ results in the formation of atmospheric sulfate aerosols and sulfuric acid, which affect the chemistry, acidity, and clouds of the marine atmosphere, thereby directly and indirectly influencing the earth's radiative balance (Charlson and Rodhe, 1982; Charlson et al., 1987). $\mathrm{SO}_{2}$ is also emitted during anthropogenic fossil fuel combustion together with $\mathrm{NO}_{\mathrm{x}}$ and $\mathrm{CO}_{2}$. It is a principal air pollutant, due to its contribution to atmospheric aerosol formation and atmospheric acidity (Capaldo et al., 1999; Smith et al., 2011). SO 2 -derived aerosols are considered to have a net cooling effect on the atmosphere (Forster et al., 2007).

The harmful effects of sulfuric acid deposition to land-based ecosystems are long-recognized (Galloway et al., 1983). This has led to strict regulations on land-based sources of $\mathrm{SO}_{2}$ (e.g., power stations, vehicular emissions) resulting in significant reductions in the sulfur burden over North America and Europe. Despite evidence of enhanced acidification in coastal regions via the deposition of sulfur and nitric acids to the surface ocean (Doney et al., 2007), emissions from shipping have been poorly regulated. As a result, ships have continued to burn low-grade, highsulfur content fuel, and are consequently responsible for a large proportion of man-made $\mathrm{SO}_{2}$ emissions. It was estimated that in the year $2000 \mathrm{SO}_{2}$ emissions from shipping were around threefold greater than that from all road traffic and aviation combined (Eyring et al., 2005).

\section{Nitrogen}

Ship traffic in the Baltic Sea is the fourth largest emitter of $\mathrm{NO}_{\mathrm{x}}$. The atmospheric oxidation of $\mathrm{NO}_{\mathrm{x}}$ results in formation of nitrate aerosols and nitric acid. According to a recent Helsinki Commission (HELCOM) report, atmospheric nitrogen deposition derived from ship stack emissions was responsible for $6 \%(13,523$ tons $)$ of total nitrogen deposition $(218,604$ tons) into the Baltic Sea in 2010 (HELCOM, 2015), thus significantly contributing to eutrophication in this region. While the total atmospheric nitrogen input to the Baltic Sea decreased during 2008-2010, nitrogen deposition from Baltic Sea shipping increased by $15 \%$ (more than 1,700 tons) compared to the reference period (1997-2003).

The total nitrogen load related to atmospheric deposition from ship exhaust is not at the same scale as the amount of nitrogen loading from waterborne sources (758,337 tons $\mathrm{N}$ in 2010, including industries and agricultural run-off) (HELCOM, 2015). Nonetheless, it may have considerable effects on the productivity of pelagic phytoplankton in offshore regions away from the influence of agricultural runoff, as these nutrients are immediately available for uptake by planktonic microorganisms. Ship-derived nitrogen directly entering the upper mixed layer may decrease nitrogen limitation and enhance primary production and bacterial remineralization of organic 


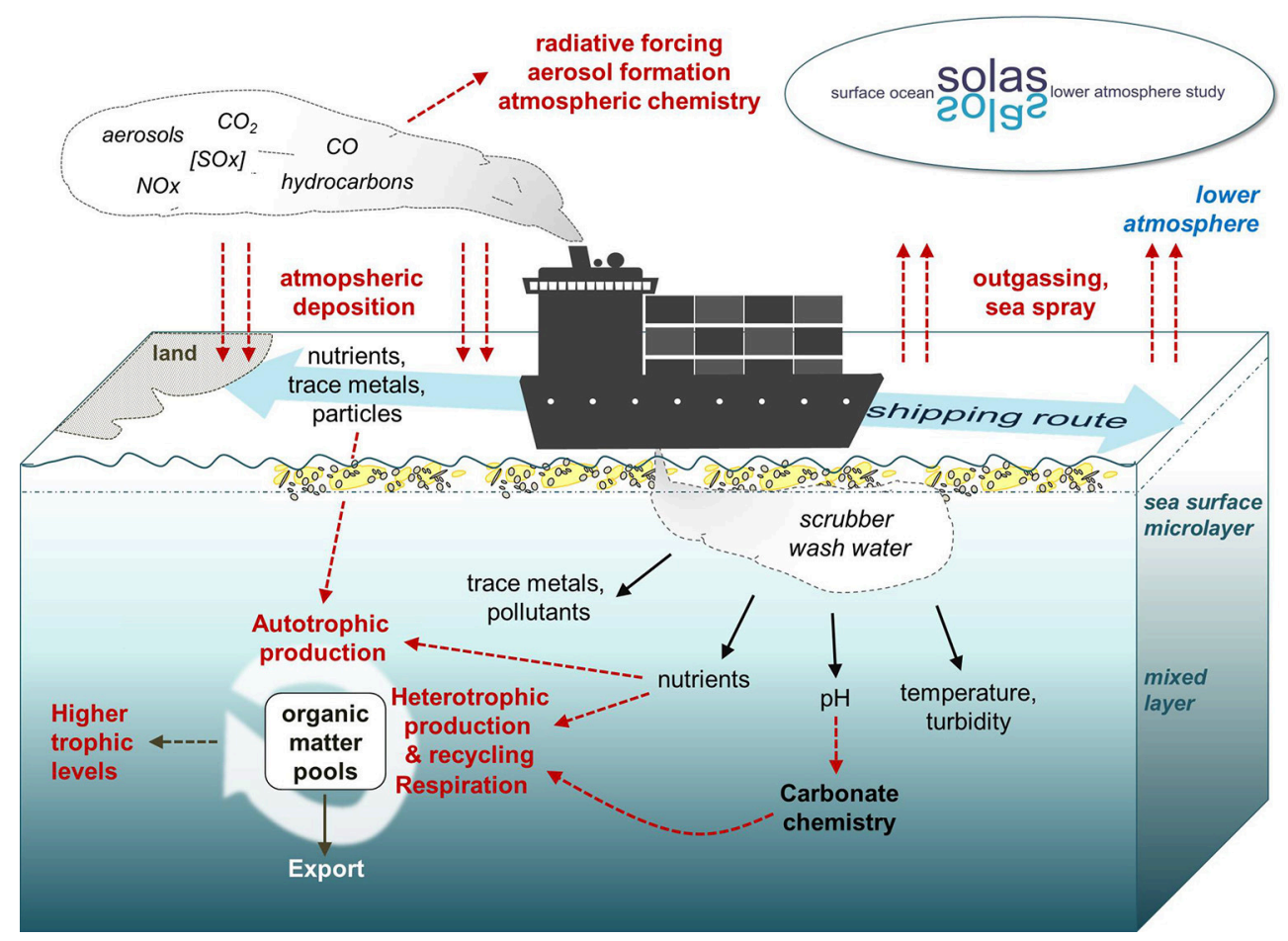

FIGURE 1 | Ship smokestack and scrubber wash water emissions at the ship-air-water interface and their potential effects on atmospheric chemistry and marine ecosystems in the surface ocean.

matter in the oligotrophic open ocean (Bonnet et al., 2005; Pulido-Villena et al., 2008).

In contrast, coastal areas and semi-enclosed basins are already overloaded by emissions and human activities, leading to high levels of nutrients and pollutants. Additional nitrogen from exhaust deposition and scrubber effluents concentrates along shipping routes in the upper mixed layer and likely affects biological nitrogen cycling, especially during summer months when cruise ship operation peaks (HELCOM, 2017).

\section{Carbon Dioxide}

On a global scale, oceanic uptake of anthropogenic $\mathrm{CO}_{2}$ emissions has already caused a $\mathrm{pH}$ decrease of 0.1 compared to the pre-industrial era (Caldeira and Wickett, 2003; Feely et al., 2009). A further decrease of 0.3 is expected by the end of this century (Orr et al., 2005; Feely et al., 2009). The effects of ocean acidification may be more significant in coastal regions than the open ocean, as such regions are already subject to an array of anthropogenic stressors, including eutrophication, pollution, and overfishing. Furthermore, the acidification process is enhanced by the deposition of anthropogenic $\mathrm{SO}_{\mathrm{x}}$ and $\mathrm{NO}_{\mathrm{x}}$ (Doney et al., 2007), some of which is derived from ship stack emissions. This additional acid burden from shipping may also be significant in the open ocean. It has been estimated that emissions of $\mathrm{SO}_{\mathrm{x}}$ and $\mathrm{NO}_{\mathrm{x}}$ in the heavily trafficked waters of the open ocean could lead to significant regional $\mathrm{pH}$ reductions of the same order of magnitude as anthropogenic $\mathrm{CO}_{2}$-driven acidification (Hassellöv et al., 2013; Stips et al., 2016). This is particularly the case if the effects of acidic scrubber wash water are also included (Stips et al., 2016). Strong acid deposition can also affect the ability of the oceans to take up $\mathrm{CO}_{2}$ : a modeling study in the Baltic Sea indicates that each mole of strong acid deposited results in a 0.8 mole reduction in $\mathrm{CO}_{2}$ uptake (Turner et al., 2017a).

\section{Particulate Matter and Aerosols}

The heavy burden of combustion-associated gases and particles $\left(\mathrm{PM}, \mathrm{SO}_{\mathrm{x}}, \mathrm{NO}_{\mathrm{x}}\right.$, and $\left.\mathrm{CO}\right)$ in densely populated coastal areas, particularly those located near busy sea ports, is of concern due to the potential negative health effects, especially those associated with human exposure to PM. Ambient levels of small particulate matter $\left(\mathrm{PM}_{2.5}\right.$, the mass of particles with an aerodynamic diameter less than $2.5 \mu \mathrm{m}$ ) have been linked to a variety of health effects including asthma and heart attacks, and increases in $\mathrm{PM}_{2.5}$ are closely associated with premature mortalities relating to heart disease and lung cancer (Winebrake et al., 2009). Predictions from air-quality models suggest that ship-derived PM may contribute to tens of thousands of cases of premature mortality near coastlines every year (Corbett et al., 2007; Winebrake et al., 2009).

In addition to decreasing $\mathrm{pH}$ in the marine environment, combustion and scrubber residues may also lead to increases in temperature and turbidity, as well as the introduction of further pollutants, such as heavy metals, black carbon, PAHs, and other organic compounds. As these compounds may have long lifetimes in seawater, their potential long-term accumulation needs to be considered (Lange et al., 2015a). 


\section{LEGAL REGULATIONS TO REDUCE SURFACE OCEAN POLLUTION FROM SHIPPING}

\section{The International Maritime Organization (IMO) and MARPOL}

The International Maritime Organization (IMO) serves as the central international forum for the negotiation of shippingrelated issues and the adoption of international legally binding rules and standards for states and the shipping industry. The 1973/1978/1997 International Convention for the Prevention of Marine Pollution from Ships (MARPOL) is one of the most important sources of environmental regulation of the shipping industry. The IMO's Marine Environment Protection Committee (MEPC), the main committee for addressing environmental issues falling under the IMO's mandate including vesselsource pollution, is responsible for the adoption and ongoing actualization of the Convention's technical annexes, which address different categories of pollutants: oil and oily water (Annex I), noxious liquid substances in bulk (Annex II), harmful substances in packaged form (Annex III), sewage (Annex IV), garbage (Annex V), and air pollution (Annex VI).

\section{MARPOL Annex VI and the Regulation of Air Pollution From Ships}

Annex VI of MARPOL was adopted through a Protocol of 1997, which finally entered into force on 19 May 2005. As of 8 November 2017, 88 contracting states have ratified the Annex VI Protocol-totalling 96\% of the gross tonnage of the world's combined merchant fleet (IMO). Annex VI seeks to limit the emissions of the main air pollutants contained in ships' exhaust gas, including $\mathrm{SO}_{\mathrm{x}}, \mathrm{NO}_{\mathrm{x}}$, and $\mathrm{PM}$, prohibits deliberate emissions of ozone-depleting substances, and regulates shipboard incineration as well as the emissions of VOC from tankers.

In October 2008, the MEPC adopted the revised MARPOL Annex VI and the associated $\mathrm{NO}_{\mathrm{x}}$ Technical Code 2008 (Resolution MEPC 176) ${ }^{2}$. This included a reduction of the global sulfur cap from 3.50 to $0.50 \%$ (Table 1). After assessing the fuel availability to meet the $0.50 \%$ standard, the MEPC endorsed this sulfur cap on fuels from 1 January 2020 at its 70th session on 28 October 2016 (Resolution MEPC 280) 2 .

MARPOL Annex VI also introduced emission control areas (ECAs), initially focused on sulfur emissions only and called SECAs (sulfur emission control areas), which aim to reduce emissions of air pollutants in designated sea areas. ECAs are areas where the adoption of special mandatory measures for ships is required to prevent, reduce and control air pollution. They are not limited to $\mathrm{SO}_{\mathrm{x}}$, but can also deal with $\mathrm{PM}$ and $\mathrm{NO}_{\mathrm{x}}$

\footnotetext{
${ }^{2}$ Resolution MEPC 176. Amendments to the Annex of the Protocol of 1977 to amend the International Convention for the Prevention of Pollution from Ships, 1973, as modified by the Protocol of 1978 relating thereto (Revised MARPOL Annex VI). Report of the MEPC on its fifty-eight session, MEPC 58/23/Add.1, Annex 13.

${ }^{3}$ Resolution MEPC 280. Effective Date of the Implementation of the Fuel oil Standard in Regulation 14.1.13 of MARPOL Annex VI. Report of the MEPC on its seventh session, MEPC 70/18/Add1, Annex 6.
}

TABLE 1 | History of sulfur limits for shipping fuel for sulfur emission control areas (ECAs) and in all other sea areas.

\begin{tabular}{llc}
\hline & Date of regulation & $\begin{array}{c}\text { Sulfur limits for } \\
\text { fuel }(\% \mathbf{~ m} / \mathbf{m})\end{array}$ \\
\hline $\begin{array}{l}\text { Sulfur emission control } \\
\text { areas (ECAs) }\end{array}$ & -before 1 July 2010 & $1.5 \%$ \\
& 1 July 2010--1 Jan 2015 & $1.0 \%$ \\
& 1 Jan 2015-present & $0.1 \%$ \\
Other sea areas & Before January 2012 & $4.5 \%$ \\
& 1 January 2012--1 Jan 2020 & $3.5 \%$ \\
& After 1 Jan 2020 & $0.5 \%$ \\
\hline
\end{tabular}

(MARPOL, 2017). Five sulfur emissions control areas with tighter emissions controls were designated including the Baltic Sea, the North Sea, the North American area, including most of US and Canadian coast, and the US Caribbean Sea area (Figure 2). In the ECAs, the sulfur content of fuel oil used by ships has been limited to less than $0.10 \%$ since 2015 (Table 1). Both American ECAs are also $\mathrm{NO}_{\mathrm{x}}$ emission control areas (NECA). The North Sea and the Baltic Sea will become $\mathrm{NO}_{\mathrm{x}}$ control areas beginning on 1 January 2021 (MARPOL, 2017). Furthermore, several other areas have been designated in national or regional legislation in which particular sulfur limits in fuel oil apply, such as in EU ports outside ECAs $(0.10 \%)$ (EU, 2016), the Shenzhen Port Area, Hong Kong harbor, ports in the Yangtze River Delta, the Pearl River Delta, and the Bohai Sea $(0.50 \%)$ (NEPIA) ${ }^{4}$. Reductions in sulfur emissions of this magnitude are expected to be beneficial for human health by reducing premature mortality rate in coastal regions by up to $50 \%$ (Winebrake et al., 2009).

With respect to the control of greenhouse gas emissions, a 2011 amendment of Annex VI was endorsed, which introduced two new mandatory energy efficiency measures known as the Energy Efficiency Design Index (EEDI) for new ships and the Ship Energy Efficiency Management Plan (SEEMP) for existing ships (Tanaka, 2016). The EEDI requires a minimum energy efficiency level per capacity mile (e.g., ton mile) for different ship type and size segments. It is a non-prescriptive, performancebased mechanism that leaves the choice of technologies to use in a specific ship design to the industry such as novel machinery technologies, lowering speed, voyage optimization tools or propulsion, and hull improvements. Although these regulations are commendable, it remains to be seen whether these regulations will contribute substantially to global greenhouse gases reductions.

\section{UNCLOS Obligations Applicable to the Use of Scrubbers}

In addition to MARPOL, the United Nations Convention on the Law of the Sea (UNCLOS, 1982) provides a general legal framework to protect and preserve the marine environment

${ }^{4}$ NEPIA. New Emission Control Areas in China. Available online at: http://www. nepia.com/insights/signals-online/regulation/new-emission-control-areas-inchina/new-emission-control-areas-in-china/ (Accessed March 04, 2017). 


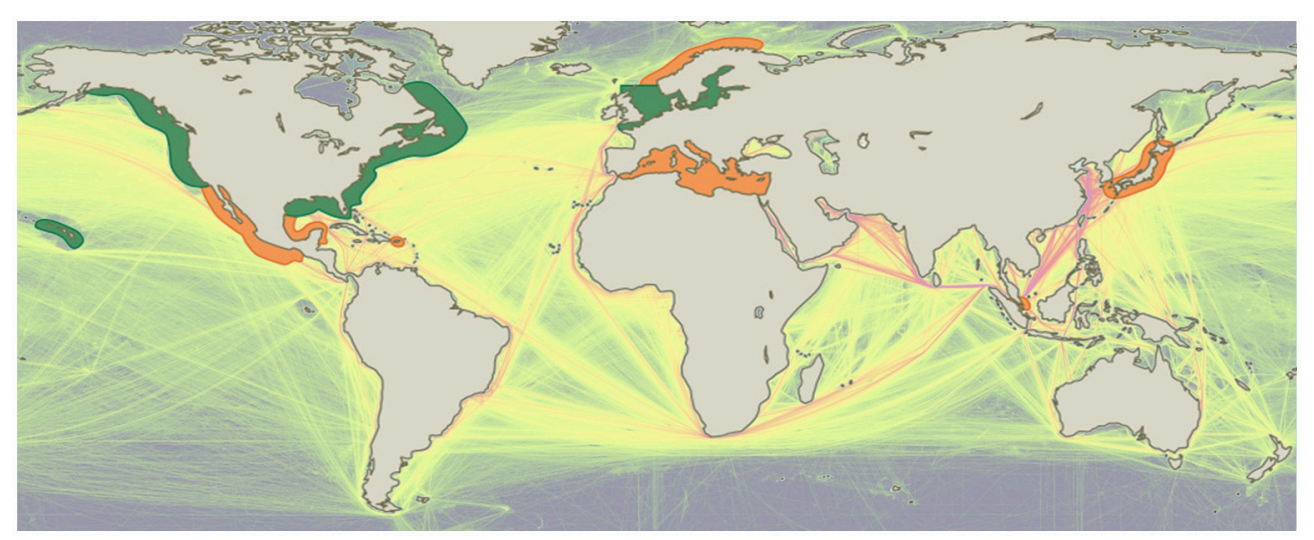

FIGURE 2 | Global shipping activities based on AIS data (data from Johansson et al., 2017) and locations of existing ECAs in green and possible ECAs in orange (map source: Exzellenzcluster Ozean der Zukunft International Ocean Institute, 2015).

and to take all necessary measures to prevent, reduce, and control marine pollution. In situations where maritime activities are under-regulated or insufficiently regulated such as those discussed here, these more general obligations establish that states are nonetheless required to undertake necessary and appropriate measures. Articles 192-196 UNCLOS apply to the main sources of pollution (land-based, dumping, vessels) including ship emissions and the use of scrubbers. Of particular relevance, Article 194 (1) UNCLOS requires states to take all measures to address pollution of the marine environment from any source, using the "best practicable means" at their disposal. Further, Article 194 (2) UNCLOS requires that states must ensure that all activities under their jurisdiction or control do not cause damage by pollution to other states and their environment and do not spread beyond areas where they exercise sovereign rights. This places a particular onus on flag states to address wash water management when port facilities do not satisfy minimum environmental standards. Article 194 (3) then provides examples of issues to be addressed by such measures, including "the release of toxic, harmful, or noxious substances, especially those which are persistent, [...] from or through the atmosphere or by dumping" and "pollution from vessels." States are also legally required in Article 195 UNCLOS "not to transfer, directly or indirectly, damage or hazards from one area to another or transform one type of pollution into another," which is the case with open- and hybrid-loop scrubber systems if discharging insufficiently treated wash water and transforming air pollution into water pollution. Article 196 UNCLOS requires states to "take all measures necessary to prevent, reduce, and control pollution of the marine environment resulting from the use of technologies under their jurisdiction or control."

The prevention, reduction, and control of ships' emissions are the responsibility of flag states for vessels flying their flag [Article 211 (2) UNCLOS]. These states have an obligation to adopt laws and regulations that meet or exceed "generally accepted international rules and standards" to fulfill these objectives. Rules and standards are adopted in the IMO, which is considered the "competent international organization" [Article 211 (2)
UNCLOS]. However, control and enforcement is also done by port states due to poor performances of flag states in this respect (Article 218 UNCLOS). Because port facilities are located in the internal waters of states, port states have full sovereignty over their ports and can adopt their own more stringent regulations concerning scrubber wash water and even prohibit its disposal irrespective of the IMO's set discharge standards in accordance with Article 211 (3) UNCLOS. UNCLOS does not mention a duty for port states to ensure adequate reception facilities for exhaust cleaning residues, nor for other harmful substances that may not be discharged into the sea. This obligation can be found in MARPOL.

Viewed together, Articles 192-196 UNCLOS address, albeit only generally, a number of the deficits surrounding the regulation of scrubbers applicable in the absence of more specific regulation under MARPOL. These provisions notably take a source-based approach to pollution. Further, important from the perspective of surface ocean-lower atmosphere interactions, these provisions fully anticipate both the more indirect deposition of exhaust "from or through the atmosphere" [Article 194 (3)] and the direct discharge of effluents and wash water into the marine environment resulting from the use of scrubber technology (Article 196).

\section{OPTIONS FOR SULFUR EMISSION REDUCTION}

\section{Exhaust Gas Cleaning Systems ("Scrubber") and Residues}

The increased costs associated with high-quality, low-sulfur content fuel have made exhaust gas cleaning systems (EGCS), also known as "scrubbers," an attractive and viable alternative for shipping companies. MARPOL Annex VI, Regulation 4 states that scrubbers can be used if the exhaust after the scrubber treatment contains equivalent or lower SOx than emissions from engines using low-sulfur fuel. However, little is known about the chemical composition of the scrubber effluent and its consequences for marine life and biogeochemical processes. 
Three types of wet scrubbers are commonly used-open or closed loop systems and hybrid systems. Wet scrubbers use seawater or fresh water as cleaning media for sulfur dioxide $\left(\mathrm{SO}_{\mathrm{x}}\right)$ producing sulfurous acid, sulfuric acid, and calcium sulfate. In contact with fine dispersed water, $\mathrm{SO}_{2}$ dissolves and is removed from the exhaust gas. The natural buffering capacity of seawater or freshwater amended with sodium hydroxide are used to neutralize the acid ions formed in this process.

$$
\begin{aligned}
\mathrm{SO}_{2} \text { (gas) }+\mathrm{H}_{2} \mathrm{O}+1 / 2 \mathrm{O}_{2} & \rightarrow \mathrm{SO}_{4}^{2-}+2 \mathrm{H}^{+} \\
\mathrm{HCO}_{3}^{-}+\mathrm{H}^{+} & \rightarrow \mathrm{CO}_{2}+\mathrm{H}_{2} \mathrm{O}
\end{aligned}
$$

The wash water obtained from the scrubbing process has a very low $\mathrm{pH}$ value $(\mathrm{pH} 3)$ and elevated temperatures. Contaminations in the wash water include PAHs and heavy metals (e.g., vanadium, nickel, and lead, Table 2) but also increased nitrate concentrations (Buhaug et al., 2006; Hansen, 2012).

In open loop scrubbers, the water flow rate into the scrubber depends on the alkalinity in the sea water. In areas with low $\mathrm{pH}$ buffering capacity, e.g., in the Baltic Sea, a higher flow rate is necessary for an effective scrubbing (Karle and Turner, 2007). If alkalinity is too low, open loop scrubbers cannot be used or need to be amended with sodium hydroxide to increase the buffering capacity. Water temperature also has an impact on the efficiency of open loop scrubbers, as higher temperatures reduce the solubility of $\mathrm{SO}_{2}$. The average flow rate of the wash water in open loop operation is around $45 \mathrm{~m}^{3} \mathrm{MWh}^{-1}$.

Closed loop or fresh water scrubbers use fresh water in a circuit supplemented with sodium hydroxide on an average flow rate of $20 \mathrm{~m}^{3} \mathrm{MWh}^{-1}$. Once scrubbed, the wash water is treated to remove the scrubbing products and pumped back into the system. A minor fraction of the wash water, so called "bleedoff" ( $\left.\sim 0.1 \mathrm{~m}^{3} \mathrm{MWh}^{-1}\right)$ is discharged. Closed loop systems can also operate for short periods without any discharge. Some closed loop scrubbers with a limited discharge rate can also use seawater for scrubbing: the discharge rate is then set by the need to avoid precipitation of calcium sulfate as the sulfate concentration of the seawater increases during operation.

Hybrid systems can switch between the open and closed wet system modes of operation. The wash water is collected in holding tanks and disposed of in port reception facilities or into the open sea. Currently approximately 50\% of ships equipped with scrubbers use hybrid systems and $40 \%$ use openloop systems (Plötzke, 2015). Rates of compliance to emission limits in the Baltic Sea ECA are high (90-95\%, Mellqvist et al., 2017). However, ships experience new challenges and temporal malfunctioning of the scrubber systems on board such as problems with sensors or biofouling in the scrubber system which may lead to temporal violation of the emission limits.

Before discharge (open loop) or recirculation (closed loop) of the scrubber wash water, it can be cleaned in order to remove the so-called "scrubber sludge" containing PM, heavy metals, and partially oily residues. Depending on the type of scrubber, different technologies are used, e.g., cyclonic separators (Den Boer and Hoen, 2015). Open loop systems additionally use sea water to dilute the wash water until it meets the established limits for $\mathrm{pH}$, turbidity, $\mathrm{PAH}$, and nitrate, before it can be discharged to the sea. The exact composition of the collected scrubber sludge is determined mainly by the fuel composition and the combustion process. One cruise ship with approximately 2,700 passengers operating in open-loop mode produces around $7 \mathrm{~m}^{3}$ of sludge per week (Damm, 2015). Scrubber sludge must be stored on board in a separate tank. Wash water residues generated by exhaust gas cleaning shall not be discharged at sea and must be delivered ashore to appropriate collection systems in ports [(MARPOL, 2017); Resolution MEPC 199(62) ${ }^{5}$; Resolution MEPC 259(68) ${ }^{6}$ ]. As mentioned in an ongoing EU survey, sludge is generally not being collected on ships using scrubbers in open loop mode, which results in the discharge of non-diluted, non-filtered wash water including all contaminants (European Commission, 2017).

\section{Environmental Aspects of Scrubber Residues}

When using scrubbers, ships are expected but not obligated to monitor several chemical and physical parameters in their exhaust and resulting wash water. Resolution MEPC 184(59) (2009) (IMO) point ten specifies limits for key operating parameters in the wash water such as $\mathrm{pH}$, turbidity (as a measure of PM), and PAHs. Ship classification organizations such as Lloyd's Register and DNV GL have established technical standards for the construction and operation of scrubbers and require that appropriate monitoring instruments are installed. Wash water $\mathrm{pH}$ has to be sufficiently high to guarantee a $\mathrm{pH}$ no lower than 6.5 at $4 \mathrm{~m}$ from the discharge point. Turbidity in the wash water must not exceed 25 formazin nephelometric units (fnu) or 25 nephelometric turbidity units (ntu) above inlet turbidity. Not more than $12 \%$ of the $\mathrm{NO}_{\mathrm{x}}$ in the exhaust converted to nitrate is allowed in the discharged wash water.

Some of the commonly applied monitoring methods are scientifically questionable in terms of their significance: e.g., the fluorescence signal characteristic for one single compound, phenanthrene, is used as indicators of all PAHs emitted from combustion. PAHs are typically found as complex mixtures in the environment. Therefore, phenanthrene concentrations may differ from total PAH concentrations (U.S. EPA, 2011). Another example is the use of turbidity in order to determine PM concentrations. This method is problematic, as its measurements depend on the scattering of light, which is influenced also by the amount of organics in the seawater, and the type of light source used. Moreover, smaller particles have a very low influence on the turbidity (U.S. EPA, 2011).

Besides $\mathrm{SO}_{\mathrm{x}}$ and $\mathrm{CO}_{2}$, exhaust contains $\mathrm{OC}, \mathrm{BC}$, ash, and other inorganic compounds, some of them from the diesel fuel and other from the lubrication oil which also end up in the wash water (U.S. EPA, 2011). On-board measurements of the size distribution of aerosol particles from smoke stacks show that small particles make up the largest portion of emissions and that the highest numbers of particles fall within particle diameter (Dp) range of $30-50 \mathrm{~nm}$. Measurements of the particle number size

\footnotetext{
${ }^{5}$ Resolution MEPC 199(62). Guidelines for Reception Facilities Under MARPOL VI. Report of the MEPC on its sixty-second session, MEPC 62/24, Annex 7.

${ }^{6}$ Resolution MEPC 259(68). (2015). Guidelines for Exhaust Gas Cleaning Systems. Report of the MEPC on its sixty-eight session, MEPC 68/21/Add.1, Annex 1.
} 
TABLE 2 | Results of the chemical analysis ( $\mathrm{pH}$, heavy metals, and PAH concentration) of seawater in the inlet and the outlet of open-loop scrubbers in comparison to seawater in the harbor; (BD is below detection).

\begin{tabular}{|c|c|c|c|c|c|c|c|c|}
\hline \multirow{4}{*}{$\begin{array}{l}\text { Type of fuel } \\
\text { Seawater } \\
\text { sampling point }\end{array}$} & \multirow{2}{*}{\multicolumn{3}{|c|}{$\begin{array}{l}\text { A: Open-loop scrubber system of Magnolia } \\
\text { Seaways (DFDS Seaways AB); (Koski et al., } \\
\text { 2017) } \\
\text { Heavy fuel IFO (intermediate fuel oil) } 380 \text { with } \\
2.5 \% \text { sulfur content }\end{array}$}} & \multicolumn{5}{|c|}{$\begin{array}{l}\text { B: Open-loop scrubber system of Ficaria Seaways (DFDS Seaways } \\
\qquad \text { AB); (Kjølholt et al., 2012) }\end{array}$} \\
\hline & & & & \multicolumn{5}{|c|}{ Heavy fuel HFO with 2.2 and $1.0 \%$ sulfur content } \\
\hline & \multirow{2}{*}{$\begin{array}{c}\text { Copenhagen } \\
\text { Harbor } \\
\text { "Langelinien" }\end{array}$} & \multirow[t]{2}{*}{ Scrubber inlet } & \multirow[t]{2}{*}{$\begin{array}{l}\text { Scrubber } \\
\text { outlet }\end{array}$} & \multirow[t]{2}{*}{$\begin{array}{l}\text { Scrubber } \\
\text { inlet }\end{array}$} & \multicolumn{2}{|c|}{$\begin{array}{l}\text { Scrubber outlet } \\
(2.2 \% \text { sulfur content })\end{array}$} & \multicolumn{2}{|c|}{$\begin{array}{l}\text { Scrubber outlet } \\
\text { (1\% sulfur content) }\end{array}$} \\
\hline & & & & & $\begin{array}{l}\text { High engine } \\
\text { load }\end{array}$ & $\begin{array}{l}\text { Low engine } \\
\text { load }\end{array}$ & $\begin{array}{l}\text { High engine } \\
\text { load }\end{array}$ & $\begin{array}{l}\text { Low engine } \\
\text { load }\end{array}$ \\
\hline Vanadium $\left[\mu \mathrm{g} \mathrm{L}^{-1}\right]$ & 0.63 & 4.2 & 1624 & 1.8 & 180 & 81 & 49 & 25 \\
\hline Nickel $\left[\mu \mathrm{g} \mathrm{L}^{-1}\right]$ & $\mathrm{BD}$ & 3.2 & 41 & 8.9 & 43 & 20 & 19 & 9.1 \\
\hline Lead $\left[\mu \mathrm{g} \mathrm{L}^{-1}\right]$ & $\mathrm{BD}$ & $\mathrm{BD}$ & 0.61 & $<0.20$ & 21 & 3.6 & 5.8 & 3.8 \\
\hline $\mathrm{pH}$ & & & & 7.8 & 3.7 & 5.2 & 5.5 & 5.8 \\
\hline $\mathrm{PAH}\left[\mu \mathrm{g} \mathrm{L}^{-1}\right]$ & & & & $\mathrm{BD}$ & 0.96 & 1.1 & 1.8 & 1.6 \\
\hline
\end{tabular}

distribution and mass before and after scrubbing show that these measurements do not decrease equally. While $60-90 \%$ of the PM mass is removed from the exhaust and suspended in the wash water (Den Boer and Hoen, 2015), the number of particles is reduced only by $30-60 \%$ during the scrubbing process (Køcks et al., 2013). Heavy metals in the wash water originate from piping, other materials in the system (often as a result of the low $\mathrm{pH}$ ) and from the fuel. The MEPC 2015 Guidelines [Resolution MEPC 259(68)] do not include limits for heavy metals in the wash water. European directive 2008/105/EC on environmental quality standards (EQS) defines thresholds for heavy metals in surface waters including European coastal zones and both North and Baltic Sea ECAs outside the national territorial waters (EU, 2008).

So far, few studies sampled and analyzed scrubber wash water for heavy metals and other pollutants. In order to identify background concentrations, scrubber wash water samples at the outlet were compared to seawater at the ship's inlet and from the harbor (Kjølholt et al., 2012; Koski et al., 2017). The determined concentrations of nickel, vanadium, lead, and $\mathrm{PAH}$ are summarized in Table 2. The amount of vanadium and nickel in scrubber wash water was depending on fuel type (sulfur content) and engine load (high or low) (Kjølholt et al., 2012). Also, long-chain PAH and metals were mainly attached to particles in the scrubber water.

Two assessment models tested the impact of exhaust gas scrubbers on the marine environment based on seawater samples taken from heavy traffic areas around Denmark (Kjølholt et al., 2012) and Germany (Lange et al., 2015a). Kjølholt et al. calculate that in an "all ships" scenario heavy metal and $\mathrm{PAH}$ concentrations in seawater would stay below the current European EQS. However, as long-chain PAH and metals attach to particles in the scrubber water, those low concentrations may be explained by fast sedimentation and accumulation of the particles on the seafloor (Kjølholt et al., 2012). Furthermore, high variability of the background concentrations in the water over time and release by other sources of pollutions (Kjølholt et al., 2012) need to be considered in risk assessments. Lange et al. conclude that the long-term accumulation of heavy metals in ecologically sensitive areas due to increase scrubber use and related wash water discharge will likely impact the marine environment (Lange et al., 2015a).

The MEPC 2015 Guidelines state that the environmental criteria for scrubber residues need updating and that ship owners and scrubber manufacturers are requested to additionally monitor $\mathrm{pH}, \mathrm{PAH}$, oil, $\mathrm{NOx}$, and heavy metals such as cadmium, copper, nickel, lead, zinc, arsenic, chromium, and vanadium in the wash water.

We conclude, that despite the existing guidelines for levels of monitoring and compliance of scrubber wash water, there is still the risk for acidification, eutrophication, and accumulation of PAHs, PM, and heavy metals in the marine environment, especially in the ecologically sensitive coastal regions, with often already higher background concentrations of contaminants and less dilution compared to the open sea (Den Boer and Hoen, 2015). It is therefore crucial to improve spatial and temporal measurements of pollutants along shipping lanes and in ports.

The impact of scrubber wash water discharge on marine microorganisms and biogeochemical processes has so far only been measured in one study (Koski et al., 2017). It reported increased adult zooplankton mortality and reduced feeding probably due to the synergistic effects of heavy metals and other constituents in the scrubber wash water. However, there are plenty of studies on the effects of some of the scrubber constituents (e.g., metals and $\mathrm{PAH}$ ) on marine life and marine organisms.

While some trace metals are essential cofactors in enzymatic processes, all metals are toxic for marine life at elevated concentrations. In combination with lowered $\mathrm{pH}$, as found in scrubber wash water, the solubility of metals in seawater, the mobilization of metals from particles, and consequently the toxicity of metals increase (Ivanina and Sokolova, 2015). Yet, 
bacteria and some phytoplankton species may be able to tolerate high lead concentration, and even benefit from lead-induced death of their grazers (Fernandez Leborans et al., 1998; Echeveste et al., 2014). Trace metals accumulate in cells and animal tissue and are transmitted through the trophic webs to higher biotic levels. Bivalves such as Mytilus sp. are successfully used as indicator organisms in environmental monitoring programs to track marine metal pollution (Chase et al., 2001).

Likewise, PAH were found to be harmful to marine microbial food webs and human health. The International Agency for Research on Cancer identified 17 PAHs as a threat to human health, some even as carcinogenic (Abdel-Shafy and Mansour, 2016). PAH addition in perturbation studies resulted in reduced phytoplankton growth rates, particularly on growth of picophytoplankton such as the widespread Prochlorococcus sp. and Synechococcus sp., and zooplankton grazing rates (Hjorth et al., 2008; Echeveste et al., 2011; Cerezo and Agustí, 2015). High-molecular-weight $\mathrm{PAH}$ absorb to phytoplankton cells (Cerezo et al., 2017) and marine particles (Abdel-Shafy and Mansour, 2016) or even are enter cells. PAH are transported through the food web and exported to marine sediments. Sediment dwelling and filter-feeding organisms (e.g., bivalve), but also shellfish and fish may accumulate PAH (AbdelShafy and Mansour, 2016) and in that way entering human food. PAH are moderately persistent in the environment and moderate to high toxicity to aquatic life (Hylland, 2006).

In order to estimate the ecological consequences of increasing operation of wet scrubbers in shipping transport, we need a sound database of the composition of wash water and its local impact on marine biogeochemistry. Future research needs to increase our understanding of the ecological and biogeochemical effects of wash water discharge from shipping considering seasonally- and spatially-variable phytoplankton communities, cumulative effects as well as interactive effects with other environmental parameters.

\section{Legal Aspects of Scrubbers and Waste Stream Discharge}

Despite the progress toward reduced atmospheric pollution from shipping, there still remains the challenge of implementation, inspection, and enforcement of emissions regulations. The use of scrubbers to meet $\mathrm{SO}_{\mathrm{x}}$ and $\mathrm{NO}_{\mathrm{x}}$ emission limits is permissible under Regulations 13 and 14 MARPOL Annex VI (MARPOL, 2017). The determination of the type of scrubber that may be used in ECAs is subject to the approval of the "Administration," defined under Article 2(5) of MARPOL as the "Government of the State under whose authority the ship is flying" (i.e., flag state), taking into account guidelines developed by the IMO (MARPOL, 2017). Numerous guidelines have been issued by the MEPC to this end. In this context, it is important to distinguish between amendments and guidelines. While provisions in Annex VI and subsequent amendments are binding on member states, MEPC and IMO guidelines are without legal significance yet request member states to incorporate the guidelines into law.

Of particular importance are the 2005 Guidelines for OnBoard Exhaust Gas-SO $\mathrm{S}_{\mathrm{x}}$ Cleaning Systems [Resolution MEPC
130(53) $]^{7}$ and the recent 2015 Guidelines for Exhaust Gas Cleaning Systems [Resolution MEPC 259(68)]. Section 17(a) of the 2005 Guidelines stipulate that the unit's wash systems should be able to "eliminate, or reduce to a level at which they are not harmful, hydrocarbons, carbon residue, ash, vanadium, other heavy metals, and other substances (...) that may have an adverse impact on ecosystems if discharged overboard". Furthermore, wash water residues should be disposed on land, and not discharged at sea or incinerated on board the ship (section 18.1).

The 2015 Guidelines provide more details on the unit design and monitoring of the wash water treatment system, and further prescribe meticulous standards pertaining to wash water discharge such as $\mathrm{pH}$ levels, $\mathrm{PAH}$ concentration, turbidity levels, nitrate levels, and an assessment of the use of chemicals such as additives and other substances (section 10). In particular, section 10.4 reiterates that wash water residues should be disposed on shore at reception facilities and should not be discharged at sea or incinerated on board the ship. The storage and disposal of those residues need to be recorded in the scrubber log, which can be part of the log-book or an electronic recording system approved by the flag state. These stipulations may be enforced via certifications issued by the flag state in accordance with its domestic/national laws (of which the IMO/MEPC guidelines would have been incorporated, subject to any modification deemed necessary).

Aside from flag states, coastal states are also keen on enforcing emission limits and the use of scrubbers, especially in coastal waters that have been designated as ECAs. Discharge of wash water into the sea is strictly regulated in those instances. Similarly, port states have an interest in ensuring that ships calling into port do not discharge wash water into the sea. Thus, Regulation 14(4)(b) of Annex VI (MARPOL, 2017) stipulates that where scrubbers are used, the "waste streams from the use of such equipment shall not be discharged into enclosed ports, harbors and estuaries unless it can be thoroughly documented by the ship that such waste streams have no adverse impact on the ecosystems of such enclosed ports, harbors, and estuaries." The port state is at liberty to determine these criteria. Nevertheless, in such instances where the discharge of waste residues in the marine environment is not permitted, the port state is required to provide reception facilities to meet the needs of ships in disposing of them, without causing undue delay to ships [MARPOL, 2017; Resolution MEPC 217(63) ${ }^{8}$ ]. Ports have a rather soft obligation to ensure that port reception facilities for exhaust gas cleaning residues from scrubbers are available. Exceptions can be made upon informing the IMO, which then informs all IMO members when a port or terminal is remotely located or lacks the industrial infrastructure necessary to manage and process

\footnotetext{
${ }^{7}$ Resolution MEPC 130(53). Guidelines for On-Board Exhaust Gas-SOX Cleaning Systems. Report of the MEPC on its fifty-third session, MEPC 53/24/Add.1, Annex 2.

${ }^{8}$ Resolution MEPC 217(63). Amendments to the Annex of the Protocol of 1977 to amend the International Convention for the Prevention of Pollution from Ships, 1973, as Modified by the Protocol of 1978 Relating Thereto (Regional Arrangements for Port Reception Facilities under MARPOL Annex VI and Certification of Marine Diesel Engines Fitted with Selective Catalytic Reduction Systems Under NOX Technical Code 2008. Report of the MEPC on its sixty-third session, MEPC 63/23/Add., Annex 21.
} 
those substances and therefore cannot accept them [Regulation 17 (2) of Annex VI (MARPOL, 2017)]. The 2011 Guidelines for Reception Facilities under MARPOL Annex VI provides more clarity as to the obligation to accept, treat and dispose of such wastes. As an alternative solution, ports without the capacity to collect and store scrubber residues are encouraged to conclude bilateral or regional agreements with ports in the region that can provide reception facilities in order to prevent ships from discharging their scrubber residues into the environment (sea and atmosphere). There should also be adequate storage capacity on board ships for scrubber residues generated during voyages in order to manage situations when port reception facilities are not available [Resolution MEPC 199(62)]. It should be stressed that the availability of port reception facilities to receive, treat and dispose scrubber residues is essential for dissuading ships from discharging those wastes at sea and ensuring that the Annex VI limits are met (La Fayette, 2001).

\section{Alternative Emission Reduction Technologies}

Besides exhaust gas cleaning systems (scrubbers), there are other options available for complying with requirements for fuel sulfur content, including fuel conversion or fuel switching (Johnson et al., 2013). Direct abatement techniques for reducing air pollution in general include novel engine technologies (MAN Diesel and Turbo, 2010), exhaust gas recirculation, direct water injections/water emulsification, selective catalytic reduction (SCR), oxidation catalyst, humid air motor, wetpacs, fuel emulsifier, and dry scrubbers (Cooper and Gustafsson, 2004; Lövblad and Fridell, 2006; Jalkanen et al., 2009). All techniques focus mainly on reducing the emissions of nitrogen oxide (Moldanová et al., 2012). Other pollutants such as PM, OC, and $\mathrm{BC}$ can be reduced (by 10-15\%) when using regenerative fuels compared to heavy fuel oil (Petzold et al., 2011). The US company AMECS (Advanced maritime emission control system) developed and patented the Maritime Emission Control System technology that reduces large ocean going ships' emissions while at berth and/or at anchor. They claim to reduce $96 \%$ of PM, $98 \%$ of $\mathrm{NO}_{\mathrm{x}}$, and $99 \%$ of $\mathrm{SO}_{2}$ by means of Exhaust Intake Bonnets that connect the vessels smokestack with an Advanced Maritime Missions Control Unit (that functions like a scrubber) mounted on an Unpowered Seagoing Barge (Caro et al., 2007). Yang et al. (2012) developed a transparent evaluation tool to help ship owners selecting the appropriate abatement technology for their ships. Still, there is a great need for interdisciplinary research comparing alternative emission reduction technologies in terms of their cleaning efficiency, economic costs, and environmental impact.

\section{FORECASTS OF SCRUBBER EMISSIONS BASED ON SHIP TRAFFIC DATA AND DATA FROM SHIPPING COMPANIES}

It is unclear whether scrubber technology is an intermediate technology for the lifetime of existing ships or whether it will become the established way to reduce atmospheric pollution by shipping. This will depend on legal regulations as well as economic aspects such as price spread between marine gas oil and heavy fuel oil, investment costs in case of existing ships (retrofit), and new build ships (Jiang et al., 2014; Lindstad et al., 2015; Lindstad and Eskeland, 2016). Accurately forecasting the effect of scrubbers on ship emission in future decades requires merging a number of relevant techniques into a comprehensive model.

While underway, commercial ships broadcast their position, speed, and other information at regular intervals via the automatic identification system (AIS) which enables vessels in the vicinity to track others to avoid collisions. Using historic AIS data, Johansson et al. (2017) provided the first model of ship emission in international sea areas. They developed a Ship Traffic Emission Assessment Model (STEAM) by means of combining an AIS data feed with a technical database consisting of emission factors and other characteristics of more than 20000 vessels. The model was extended to STEAM2 (Jalkanen et al., 2012) to enable analysis of emissions in the North and Baltic Sea (Johansson et al., 2013; Jalkanen et al., 2014, 2016) and STEAM3 (Johansson et al., 2017) to enable global assessments. Based on the assumption that ships with an annual fuel consumption of more than 4,000 tons would benefit from scrubber installation (Reynolds) ${ }^{9}$, (Johansson et al., 2013) identified 635 out of the 30,000 different ships in the European ECAs (accounting for $21 \%$ of the total fuel consumption) to be suitable for scrubber installation. These candidate ships would have a significant economic benefit if installing scrubbers (Johansson et al., 2013).

Two studies compared and evaluated the STEAM1-3 emission models and showed that calculated emissions are comparable to measured emission factors for $\mathrm{SO}_{\mathrm{x}}$ and $\mathrm{NO}_{\mathrm{x}}$ on sample inlets for approximately 300 ships in the Gulf of Finland (Beecken et al., 2015) and to airborne measurements from the ACCESS aircraft campaign in northern Norway (Marelle et al., 2016). However, model data for PM was 2-3 times higher than measured results and the STEAM2 emissions of individual ships showed large differences to in-situ measurements in ships plumes, which strengthen the need for incorporating real measurements into the models.

The Interreg IVB project Clean North Sea Shipping (CNSS) combined a database of engine load-dependent function with a database of AIS signals including emission factor functions for various engine types, vessel sizes, and pollutants (Aulinger et al., 2016). The study yielded ship emissions at high temporal and spatial resolution for the North Sea area and showed that the contribution of ships to the $\mathrm{NO}_{2}$ concentration ashore close to the sea can reach up to $25 \%$ in summer and $15 \%$ in winter. Based on different scenarios for shipping emissions in the North Sea for the year 2030 (Matthias et al., 2016), the authors conclude that compliance with regulations will reduce sulfur emission, however the contribution of shipping to $\mathrm{NO}_{2}$ will increase to $20 \%$ in 2030 . Hence, further nitrogen emission regulations will be advisable.

Precisely forecasting the overall effect of scrubbers on ship emissions as well as future scrubber emissions based on ship traffic data and data from shipping companies is a very complex

${ }^{9}$ Reynolds, K. J. Exhaust Gas Cleaning Systems Selection Guide. Prepared for Ship Operations Cooperative Program (SOCP). Seattle, WA. 
matter and requires modeling efforts which combine both economic and natural science. Specific engine characteristic data along with direct emission monitoring from various ship types (equipped with scrubber systems) are needed in order to correctly predict ship type specific emissions. Various techniques exist to monitor ship emissions in-situ but also bring along certain limitations: Direct (ship specific) emission monitoring has relatively high costs and is sensitive to wind, while satellite monitoring solely applies to large areas and not to individual ships. Ultraviolet cameras and sniffers from plane, helicopter, or unmanned aerial vehicle are still experimental but promising to be a reliable techniques (van Aardenne et al., 2013). To date, the global monitoring of ship emissions as well as the effect of emission reduction technologies is insufficient. We lack spatial and temporal resolved measurements of environmentally relevant pollutants along shipping lanes and in ports. Implementing these in-situ data from ship engines and plumes into existing emission assessment models (Jalkanen et al., 2012; Aulinger et al., 2016) in combination with maritime traffic predictions can improve emission forecasts which could then be included into global atmospheric models to estimate the environmental benefit of scrubber operation and the global contribution of ship emissions to atmospheric pollution.

\section{CONCLUSION}

The use of new emission reduction technologies, such as scrubbers, in the shipping industry has benefited the environment by significantly reducing the release of pollutants to the atmosphere. However, there is incomplete understanding of the impact of scrubber wash water discharge on marine chemistry, biodiversity, and biogeochemical processes. In particular, there is limited information on the amount and composition of wash water discharge and the associated marine biological impacts. The ecological consequences of increasing operation of scrubbers in shipping transport have so far only been addressed in one study (Koski et al., 2017). Its results show increased marine zooplankton mortality and reduced feeding attributed to the synergistic effects of heavy metals and other constituents in the discarded scrubber wash water. Studies on the effects of some of the scrubber constituents reveal that PAH and metals affect growth, consumption, and reproduction of marine biota. Furthermore, they accumulate through the food web and in that way entering human food. As PAHs, OCs, and heavy metals can be persistent in the marine environment, e.g., adsorbed to sediment particles, their potential long-term accumulation needs to be assessed. Future experimental studies should focus on the effects of wash water discharge from shipping in the context of seasonally- and spatially-variable phytoplankton communities, heterotrophic microorganisms, and fish breeding grounds. Both cumulative effects of different pollutants and interactive effects with other environmental parameters should be considered (Lange et al., 2015b).

Simultaneously, standards and monitoring guidelines for application of scrubbers need to be improved. IMO member states recently recognized that it is necessary to improve and harmonize procedures in terms of wash water sampling and analysis to ensure comparability in different data sets (MEPC 71/INF.19) ${ }^{10}$. Wash water measurements should include monitoring of $\mathrm{pH}$, PAHs, oil, OC, $\mathrm{BC}$, nitrogen, and heavy metals. Improved inspection protocols but also further technical developments of the scrubber systems, e.g., regarding reduction of biofouling and scrubber sensors failures, are needed to increase the compliance level national and international regulations as well as enforcement of emission reduction technologies.

By design, MARPOL Annex VI focuses on atmospheric emissions, although some consideration has been made of potential effects on the marine environment. Currently, there is great scope to further regulate ship emissions to the atmosphere and the ocean, such as the identification and creation of new ECAs (Figure 2) and the provision of more port reception facilities for advanced waste management of scrubber residues. Yet, the release of scrubber wash water to the surface ocean is under-regulated and not subject to the Environmental Risk Assessments normally required for potentially polluting discharges e.g., in the context of the EU Marine Strategy Framework Directive (Turner et al., 2017b). Over the last decades, the development of the marine regulations for $\mathrm{SO}_{\mathrm{x}}$ and $\mathrm{NO}_{\mathrm{x}}$ has been much slower compared to those regulating terrestrial transport, and notably, the sulfur content allowed in fuels used in marine ECAs is one hundred times higher than that allowed for terrestrial transport fuel in the EU. This demonstrates the considerable lag between the developments of the global IMO ship fuel regulations in contrast to regional regulation of terrestrial transport fuels (Turner et al., 2017b) although the input of organic pollutants and nutrients from shipping would be much easier to control than those from terrestrial transport and other land-based sources. Similarly, more attention should be paid to improve aspects of implementation, compliance, inspection, and enforcement. Nevertheless, the current framework enables states to control scrubber discharges in accordance with IMO/MEPC guidelines and amendments (that are constantly reviewed and updated), and provides a feasible and practical foundation with which to work.

We conclude that despite the existing guidelines for levels of monitoring and compliance of scrubber wash water, there is still the risk for acidification, eutrophication, and accumulation of pollutants in the marine environment, especially in the coastal regions, with often already higher background concentrations of contaminants and less dilution compared to the open sea (Den Boer and Hoen, 2015). Besides improving direct emission monitoring on ships, it is therefore crucial to improve spatial and temporal measurements of pollutants along shipping lanes and in ports to gain a comprehensive understanding of shipping-related pollution and the effect of emission reduction technologies. It is unclear whether scrubbers will become the established way to reduce atmospheric pollution by shipping for the next decades.

\footnotetext{
${ }^{10}$ MEPC 71/INF.19. Pollution Prevention and Response. Review of the 2015 Guidelines for Exhaust Gas Cleaning Systems (Resolution MEPC 259(68). The need for improved washwater data collection.
} 
Due to its complex nature, accurately forecasting scrubber operation and the related releases of pollutants requires further modeling efforts combining ship traffic data with ship emission factors and in-situ measurements of pollutants on-board. Using those global measurements and improving current maritime transport models, we may be able to better predict ship emissions, the use of scrubbers and their environmental impact in the future. In addition, there is a great need for interdisciplinary research comparing alternative emission reduction technologies in terms of their cleaning efficiency, economic costs, and environmental impact.

Whether scrubbers are currently the most environmentalfriendly technology is still unclear. This review identifies several interdisciplinary research priorities at the air-sea-interface which will be able to provide robust scientific data and help to improve our understanding of the potential impacts of exhaust emission reduction technologies. Our goal should be to provide information for policy recommendations and remove operational and investment uncertainty for the shipping industry in order to foster the development of a sustainable and environmentally-responsible shipping industry.

\section{AUTHOR CONTRIBUTIONS}

SE led the review, the design, and the development of the manuscript. FM, FH, KH, EMM, JO, BQ, PS, and DT made

\section{REFERENCES}

Abdel-Shafy, H. I., and Mansour, M. S. M. (2016). A review on polycyclic aromatic hydrocarbons: Source, environmental impact, effect on human health and remediation. Egypt. J. Petrol. 25, 107-123. doi: 10.1016/j.ejpe.2015.03.011

Aulinger, A., Matthias, V., Zeretzke, M., Bieser, J., Quante, M., and Backes, A. (2016). The impact of shipping emissions on air pollution in the greater North Sea region - Part 1: current emissions and concentrations. Atmos. Chem. Phys. 16, 739-758. doi: 10.5194/acp-16-739-2016

Beecken, J., Mellqvist, J., Salo, K., Ekholm, J., Jalkanen, J.-P., Johansson, L., et al. (2015). Emission factors of $\mathrm{SO}_{2}, \mathrm{NO}_{x}$ and particles from ships in Neva Bay from ground-based and helicopter-borne measurements and AIS-based modeling. Atmos. Chem. Phys. 15, 5229-5241. doi: 10.5194/acp-15-5229-2015

Bonnet, S., Guieu, C., Chiaverini, J., Ras, J., and Stock, A. (2005). Effect of atmospheric nutrients on the autotrophic communities in a low nutrient, low chlorophyll system. Limnol. Oceanogr. 50, 1810-1819. doi: $10.4319 /$ lo.2005.50.6.1810

Brévière, E., and the SOLAS Scientific Steering Committee (2016). SOLAS 20152025: Science Plan and Organisation. Kiel.

Buhaug, Ø., Fløgstad, H., and Bakke, T. (2006). "MARULS WP3: washwater criteria for seawater exhaust gas-SOx scrubbers," in MEPC 56/INF.5 ANNEX 1, (Trondheim: Norwegian Marine Technology Research Institute), 1-33.

Caldeira, K., and Wickett, M. E. (2003). Anthropogenic carbon and ocean pH. Nature 425:365. doi:10.1038/425365a

Capaldo, K., Corbett, J. J., Kasibhatla, P., Fischbeck, P., and Pandis, S. N. (1999). Effects of ship emissions on sulphur cycling and radiative climate forcing over the ocean. Nature 400, 743-746. doi: 10.1038/23438

Caro, S., Ottensen, H., and Powell, J. G. (2007). Maritime Emissions Control System; United States Patent 7258710. Rancho Dominguez, CA; United States Patent 7258710.

Cerezo, M. I., and Agustí, S. (2015). PAHs reduce DNA synthesis and delay cell division in the widespread primary producer Prochlorococcus. Environ. Pollut. 196, 147-155. doi: 10.1016/j.envpol.2014.09.023 substantial contributions to the drafting and development of the manuscript and provided feedback on all components of the manuscript. Note that all authors participated in a collaborative SOLAS workshop which led to the creation of this manuscript. All authors have seen and approved the final version of the manuscript being submitted.

\section{ACKNOWLEDGMENTS}

The authors wish to thank Christa Marandino, Erik van Doorn, the SOLAS International Project office and Scientific Steering Committee encouragement to hold this workshop and the Kooperationsstelle EU der Wissenschaftsorganisationen (KOWI) for hosting us in Brussels. This work was funded by the International Surface Ocean-Lower Atmosphere Study (SOLAS) project and the GEOMAR Helmholtz Centre for Ocean Research. SE acknowledges the support of the Cluster of Excellence 80 The Future Ocean. The Future Ocean is funded within the framework of the Excellence Initiative by the Deutsche Forschungsgemeinschaft (DFG) on behalf of the German federal and state governments. DT acknowledges financial support from the Swedish Research Council Formas, contract no. 2012-2120. EMM acknowledges the Swedish Research Council Formas, contract no. 2011-1007. FH acknowledges financial support from Plymouth Marine Laboratory.
Cerezo, M. I., Linden, M., and Agustí, S. (2017). Flow cytometry detection of planktonic cells with polycyclic aromatic hydrocarbons sorbed to cell surfaces. Mar. Pollut. Bull. 118, 64-70. doi: 10.1016/j.marpolbul.2017. 02.006

Charlson, R. J., and Rodhe, H. (1982). Factors controlling the acidity of natural rainwater. Nature 295, 683-685. doi: 10.1038/295683a0

Charlson, R. J., Lovelock, J. E., Andreae, M. O., and Warren, S. G. (1987). Oceanic phytoplankton, atmospheric sulphur, cloud albedo and climate. Nature 326, 655-661. doi: 10.1038/326655a0

Chase, M. E., Jones, S. H., Hennigar, P., Sowles, J., Harding, G. C. H., Freeman, K., et al. (2001). Gulfwatch: monitoring spatial and temporal patterns of trace metal and organic contaminants in the Gulf of Maine (1991-1997) with the Blue Mussel, Mytilus edulis L. Mar. Pollut. Bull. 42, 490-504. doi: 10.1016/S0025-326X(00)00193-4

Cooper, D., and Gustafsson, T. (2004). Methodology for Calculating Emissions from Ships: 1. Update of Emission Factors. Report series for SMED and SMED\&SLU, Norrköping.

Corbett, J. J., Winebrake, J. J., Green, E. H., Kasibhatla, P., Eyring, V., and Lauer, A. (2007). Mortality from ship emissions: a global assessment. Environ. Sci. Technol. 41, 8512-8518. doi: 10.1021/es071686z

Damm, L. (2015). "Operation experience of scrubber onboard of cruise vessels," in 9th International Symposium - Treatment of Wastewater and Waste on Ships (Hamburg).

Den Boer, E., and Hoen, M. (2015). Scrubbers - An Economic and Ecological Assessment. Delft.

Doney, S. C., Mahowald, N., Lima, I., Feely, R. A., Mackenzie, F. T., Lamarque, J.-F., et al. (2007). Impact of anthropogenic atmospheric nitrogen and sulfur deposition on ocean acidification and the inorganic carbon system. Proc. Natl. Acad. Sci. U.S.A. 104, 14580-14585. doi: 10.1073/pnas.0702218104

Echeveste, P., Agustí, S., and Dachs, J. (2011). Cell size dependence of additive versus synergetic effects of UV radiation and PAHs on oceanic phytoplankton. Environ. Pollut. 159, 1307-1316. doi: 10.1016/j.envpol.2011. 01.023 
Echeveste, P., Tovar-Sánchez, A., and Agustí, S. (2014). Tolerance of polar phytoplankton communities to metals. Environ. Pollut. 185, 188-195. doi: 10.1016/j.envpol.2013.10.029

EU (2008). Directive 2008/105/EC of the European Parliament and of the Council of 16 December 2008 on Environmental Quality Standards in the Field of Water Policy, Amending and Subsequently Repealing Council Directives 82/176/EEC, 83/513/EEC, 84/156/EEC, 84/491/EEC, 86/280/EEC and amending Directive 2000/60/EC of the European Parliament and of the Council.

EU (2016). Directive 2016/802/EU of the European Parliament and of the Council of 11 May 2016 Relating to a Reduction in the Sulphur Content of Certain Liquefied Fuels (codification), OJ L132/58, 21.05.2016.

European Commission (2017). "European sustainable shipping forum," in 7th Plenary Meeting: ESSF Sub-group on Exhaust Gas Cleaning Systems (EGCS). Brussels: United States Patent 7258710.

Exzellenzcluster Ozean der Zukunft and International Ocean Institute (2015). Sustainable Use of Our Oceans - Making Ideas Work. Hamburg: Maribus.

Eyring, V., Köhler, H. W., van Aardenne, J., and Lauer, A. (2005). Emissions from international shipping: 1. The last 50 years. J. Geophys. Res. 110:D17305. doi: 10.1029/2004JD005619

Feely, R. A., Doney, S. C., and Cooley, S. R. (2009). Ocean acidification - present conditions and future changes in a high- $\mathrm{CO}_{2}$ world. Oceanography 22, 36-47. doi: 10.5670/oceanog.2009.95

Fernandez Leborans, G., Herrero, Y. O., and Novillo, A. (1998). Toxicity and bioaccumulation of lead in marine protozoa communities. Ecotoxicol. Environ. Saf. 39, 172-178. doi: 10.1006/eesa.1997.1623

Forster, P., Ramaswamy, V., Artaxo, P., Berntsen, T., Betts, R., Fahey, D. W., et al. (2007). "Changes in atmospheric constituents and in radiative forcing," in Climate Change 2007: The Physical Science Basis. Contribution of Working Group I to the Fourth Assessment Report of the Intergovernmental Panel on Climate Change (Cambridge: Cambridge University Press).

Galloway, J. N., Norton, S. A., and Church, M. R. (1983). Freshwater acidification from atmospheric deposition of sulfuric acid: a conceptual model. Environ. Sci. Technol 17, 541A-545A. doi: 10.1021/es00117a723

Hansen, J. P. (2012). Exhaust Gas Scrubber Installed Onboard MV Ficaria Seaways: Public Test Report. Aalborg: Danish Ministry of Environment.

Hassellöv, I.-M., Turner, D. R., Lauer, A., and Corbett, J. J. (2013). Shipping contributes to ocean acidification. Geophys. Res. Lett. 40, 2731-2736. doi: $10.1002 / g r l .50521$

HELCOM (2015). Updated Fifth Baltic Sea Pollution Load Compilation (PLC-5.5): Baltic Sea Environmental Proceedings No. 145.

HELCOM (2017). Measuring the Progress for the Same Targets in the Baltic Sea

Hjorth, M., Forbes, V. E., and Dahllöf, I. (2008). Plankton stress responses from PAH exposure and nutrient enrichment. Mar. Ecol. Prog. Ser. 363, 121-130. doi: $10.3354 /$ meps 07470

Hylland, K. (2006). Polycyclic aromatic hydrocarbon (PAH) ecotoxicology in marine ecosystems. J. Toxicol. Environ. Health A 69, 109-123. doi: $10.1080 / 15287390500259327$

Ivanina, A. V., and Sokolova, I. M. (2015). Interactive effects of metal pollution and ocean acidification on physiology of marine organisms. Curr. Zool. 61, 653-668. doi: 10.1093/czoolo/61.4.653

Jalkanen, J.-P., Brink, A., Kalli, J., Pettersson, H., Kukkonen, J., and Stipa, T. (2009). A modelling system for the exhaust emissions of marine traffic and its application in the Baltic Sea area. Atmos. Chem. Phys. 9, 9209-9223. doi: 10.5194/acp-9-9209-2009

Jalkanen, J.-P., Johansson, L., and Kukkonen, J. (2014). A comprehensive inventory of the ship traffic exhaust emissions in the Baltic Sea from 2006 to 2009. AMBIO 43, 311-324. doi: 10.1007/s13280-013-0389-3

Jalkanen, J.-P., Johansson, L., and Kukkonen, J. (2016). A comprehensive inventory of ship traffic exhaust emissions in the European sea areas in 2011. Atmos. Chem. Phys. 16, 71-84. doi: 10.5194/acp-16-71-2016

Jalkanen, J.-P., Johansson, L., Kukkonen, J., Brink, A., Kalli, J., and Stipa, T. (2012). Extension of an assessment model of ship traffic exhaust emissions for particulate matter and carbon monoxide. Atmos. Chem. Phys. 12, 2641-2659. doi: 10.5194/acp-12-2641-2012

Jiang, L., Kronbak, J., and Christensen, L. P. (2014). The costs and benefits of sulphur reduction measures: sulphur scrubbers versus marine gas oil. Transpor. Res. D Transp. Environ. 28, 19-27. doi: 10.1016/j.trd.2013.12.005
Johansson, L., Jalkanen, J.-P., and Kukkonen, J. (2017). Global assessment of shipping emissions in 2015 on a high spatial and temporal resolution. Atmos. Environ. 167, 403-415. doi: 10.1016/j.atmosenv.2017. 08.042

Johansson, L., Jalkanen, J.-P., Kalli, J., and Kukkonen, J. (2013). The evolution of shipping emissions and the costs of regulation changes in the northern EU area. Atmos. Chem. Phys. 13, 11375-11389. doi: 10.5194/acp-13-11375-2013

Johnson, H., Johansson, M., Andersson, K., and Södahl, B. (2013). Will the ship energy efficiency management plan reduce $\mathrm{CO} 2$ emissions? A comparison with ISO 50001 and the ISM code. Maritime Policy Manage. 40, 177-190. doi: $10.1080 / 03088839.2012 .757373$

Karle, I. M., and Turner, D. (2007). Seawater Scrubbing - Reduction of SOx Emissions from Ship Exhausts. AGS Office at Chalmers, GMV, Chalmers University of Technology, SE-41296 Gothenburg, Sweden, p. 26.

Kjølholt, J., Aakre, S., Jürgensen, C., and Lauridsen, J. (2012). Assessment of Possible Impacts of Scrubber Water Discharges on the Marine Environment. København.

Køcks, M., Butcher, A., Mølgaard, S., Fuglsang, K., Rosenørn, T., Hansen, J. P., et al. (2013). "Shipboard characterization of a wet scrubber system during operation (part II): Influence on particle number concentration, particle size distribution and chemical composition," in ETH-Conference on Combustion Generated Nanoparticles (Zurich).

Koski, M., Stedmon, C., and Trapp, S. (2017). Ecological effects of scrubber water discharge on coastal plankton: potential synergistic effects of contaminants reduce survival and feeding of the copepod Acartia tonsa. Mar. Environ. Res. 129, 374-385. doi: 10.1016/j.marenvres.2017.06.006

La Fayette, L. D. (2001). The Marine Environment Protection Committee: the conjunction of the Law of the Sea and international environmental law. Int. J. Mar. Coast. Law 16, 155-238. doi: 10.1023/A:1011262511421

Lange, B., Markus, T., and Helfst, L. P. (2015a). "Impacts of scrubbers on the environmental situation in ports and coastal waters," in Texte 65/2015 (DessauRoßlau).

Lange, B., Markus, T., and Helfst, L. P. (2015b). Impacts of Scrubbers on the Environmental Situation in Ports and Coastal Waters. Dessau-Roßlau.

Lindstad, H. E., and Eskeland, G. S. (2016). Environmental regulations in shipping: policies leaning towards globalization of scrubbers deserve scrutiny. Transport. Res. D Transp. Environ. 47, 67-76. doi: 10.1016/j.trd.2016.05.004

Lindstad, H., Sandaas, I., and Strømman, A. H. (2015). Assessment of cost as a function of abatement options in maritime emission control areas. Transport. Res. D Transp. Environ. 38, 41-48. doi: 10.1016/j.trd.2015.04.018

Liss, P. S., Hatton, A. D., Malin, G., Nightingale, P. D., and Turner, S. M. (1997). Marine sulphur emissions. Philos. Trans. R. Soc. B Biol. Sci. 352, 159-169. doi: 10.1098/rstb.1997.0011

Lövblad, G., and Fridell, E. (2006). Experiences from Use of Some Techniques to Reduce Emissions from Ships. Gothenburg.

MAN Diesel and Turbo (2010). Exhaust Gas Emission Control Today and Tomorrow. Copenhagen.

Marelle, L., Thomas, J. L., Raut, J.-C., Law, K. S., Jalkanen, J.-P., Johansson, L., et al. (2016). Air quality and radiative impacts of Arctic shipping emissions in the summertime in northern Norway: from the local to the regional scale. Atmos. Chem. Phys. 16, 2359-2379. doi: 10.5194/acp-16-2359-2016

MARPOL (2017). MARPOL Consolidated Edition 2017. London: IMO.

Matthias, V., Aulinger, A., Backes, A., Bieser, J., Geyer, B., Quante, M., et al. (2016). The impact of shipping emissions on air pollution in the greater North Sea region - Part 2: scenarios for 2030. Atmos. Chem. Phys. 16, 759-776. doi: 10.5194/acp-16-759-2016

Mellqvist, J., Conde, V., and Becken, J. (2017). "Emission factors of gases and particles from ships observed by remote measurements from fixed and airborne platforms,". Shipping and the Environment (Gothenburg).

Moldanová, J., Fridell, E., Petzold, A., and Jalkanen, J.-P. (2012). Report on Shipping Emission Factors. TRANSPHORM Collaborative Project Deliverable D1.2.1.

Orr, J. C., Fabry, V. J., Aumont, O., Bopp, L., Doney, S. C., Feely, R. A., et al. (2005). Anthropogenic ocean acidification over the twenty-first century and its impact on calcifying organisms. Nature 437, 681-686. doi: 10.1038/nature04095

Petzold, A., Lauer, P., Fritsche, U., Hasselbach, J., Lichtenstern, M., Schlager, H., et al. (2011). Operation of marine diesel engines on biogenic fuels: modification of emissions and resulting climate effects. Environ. Sci. Technol. 45, 10394-10400. doi: 10.1021/es2021439 
Plötzke, M. (2015). "Overview on scrubber technologies," in 9th International Symposium - Treatment of Wastewater and Waste on Ships (Hamburg).

Pulido-Villena, E., Wagener, T., and Guieu, C. (2008). Bacterial response to dust pulses in the western Mediterranean: implications for carbon cycling in the oligotrophic ocean. Global Biogeochem. Cycles 22:GB1020. doi: 10.1029/2007GB003091

Resolution MEPC 184(59). (2009). Guidelines for Exhaust Gas Cleaning Systems. Report of the MEPC on its Fifty-Ninth Session. MEPC 59/24/Add.1.

Smith, S. J., van Aardenne, J., Klimont, Z., Andres, R. J., Volke, A., and Delgado Arias, S. (2011). Anthropogenic sulfur dioxide emissions: 1850-2005. Atmos. Chem. Phys. 11, 1101-1116. doi: 10.5194/acp-11-11 01-2011

Smith, T. W. P., Jalkanen, J.-P., Anderson, B. A., Corbett, J. J., Faber, J., Hanayama, S., et al. (2015). Third IMO GHG Study 2014. London.

Stips, A., Bolding, K., Macias, D., Bruggeman, J., and Coughlan, C. (2016). Scoping Report on the Potential Impact of On-board Desulphurisation on the Water Quality in SOx Emission Control Areas. Publications Office.

Tanaka, Y. (2016). Regulation of Greenhouse Gas Emissions from International Shipping and Jurisdiction of States. RECIEL 25, 333-346. doi: $10.1111 /$ reel.12181

Turner, D. R., Edman, M., Gallego-Urrea, J. A., Claremar, B., Hassellöv, I.-M., Omstedt, A., et al. (2017a). The potential future contribution of shipping to acidification of the Baltic Sea. Ambio. 47, 368-378. doi: 10.1007/s13280-017-0950-6

Turner, D. R., Hassellöv, I.-M., Ytreberg, E., and Rutgersson, A. (2017b). Shipping and the environment: smokestack emissions, scrubbers and unregulated oceanic consequences. Elem. Sci. Anth. 5:45. doi: 10.1525/ elementa. 167

U.S. EPA (2011). Exhaust Gas Scrubber Washwater Effluent. Washington, DC. UNCLOS (1982). United Nations, Treaty Series.

van Aardenne, J., Colette, A., Degraeuwe, B., Hammingh, P., Viana, M., and Vlieger, I., d. (2013). The Impact of International Shipping on European Air Quality and Climate Forcing. Publications Office.

Winebrake, J. J., Corbett, J. J., Green, E. H., Lauer, A., and Eyring, V. (2009). Mitigating the health impacts of pollution from oceangoing shipping: an assessment of low-sulfur fuel mandates. Environ. Sci. Technol. 43, 4776-4782. doi: 10.1021/es803224q

Yang, Z. L., Zhang, D., Caglayan, O., Jenkinson, I. D., Bonsall, S., Wang, J., et al. (2012). Selection of techniques for reducing shipping NOx and SOx emissions. Transp. Res. D Transp. Environ. 17, 478-486. doi: 10.1016/j.trd.2012.05.010

Conflict of Interest Statement: The authors declare that the research was conducted in the absence of any commercial or financial relationships that could be construed as a potential conflict of interest.

Copyright $\odot 2018$ Endres, Maes, Hopkins, Houghton, Mårtensson, Oeffner, Quack, Singh and Turner. This is an open-access article distributed under the terms of the Creative Commons Attribution License (CC BY). The use, distribution or reproduction in other forums is permitted, provided the original author(s) and the copyright owner are credited and that the original publication in this journal is cited, in accordance with accepted academic practice. No use, distribution or reproduction is permitted which does not comply with these terms. 